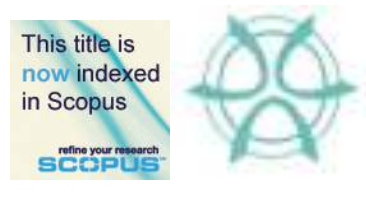

PLANNING MALAYSIA:

Journal of the Malaysian Institute of Planners

SPECIAL ISSUE IV (2016), Page 45 - 60

\title{
LEADERSHIP STYLES: INCENTIVE OR DISINCENTIVE APPROACH IN ADDRESSING STREET VENDOR PROBLEMS IN JAKARTA AND BANDUNG, INDONESIA
}

\author{
Ariva Sugandi Permana ${ }^{1}$, Norsiah Abd Aziz $^{2} \&$ Ho Chin Siong ${ }^{3}$ \\ ${ }^{1,2,3}$ Faculty of Built Environment \\ UNIVERSITI TEKNOLOGI MALAYSIA
}

\begin{abstract}
The problems of street vendors have long been experienced by most big cities in Indonesia. A newly emerged city leadership style in Jakarta and Bandung City shows two different approaches towards sustainable solution of street vendor problem. While Governor of Jakarta applies an incentive approach to street vendors by transferring them from the streets of Jakarta to appropriate place, Mayor of Bandung City applies disincentive approach to the buyers of street vendors by giving penalty to those making transaction with the vendors in "red zone". This study was undertaken in Jakarta Metropolitan, the Capital City of Indonesia and Bandung City, the Capital City of West Java Province. The choice of Jakarta and Bandung was based mainly on the new paradigm of city leadership in Indonesia as reflected by these two leaders of the city. They are both out-of-the-box leaders. Both approaches exhibit the positive results on the easiness of traffic in the area, positive image of the area as perceived by most citizens, and cleanliness.
\end{abstract}

Keyword: street vendor, city leadership, new paradigm of leadership, incentive to seller, disincentive to buyer

\section{INTRODUCTION}

Street vendors also known as Pedagang Kaki Lima (PKL) among local Indonesian have long been a dilemma for city authorities. On one hand, the street vendors provide urban employment that everyone can get hold easily. On the other hand, if the street vendors are properly managed, they may create urban environmental problems. Amid inability of the government to provide formal urban jobs for the citizens, the street vendor is an easy and short-cut answer to this persistent urban issue.

The presence of street vendors in city is due to various socio-economic and political factors, for example, urbanization process (UN, 2000; Chirisa, 2009a; Garoma, 2012), greater opportunities for earning income in cities (Charmes, 1998), insufficient supply of formal sector jobs (Charmes, 1998; Chirisa, 2009b), easy entry (ILO, 2000), rural and urban poverty (Chen, 2001; Timalsina, 2011), and urban-centered development (ILO, 2000; Suharto, 2002). The outcome of these social, political and economic factors is sometimes reflected as the incapability of the authorities to provide formal jobs (Carr 
Ariva Sugandi Permana, Norsiah Abd Aziz \& Ho Chin Siong

Leadership Styles: Incentive or Disincentive Approach in Addressing Street Vendor Problems in Jakarta and

Bandung, Indonesia

et al., 2000). ILO (2000) asserted that the challenges of the informal sector such as people engaged in informal activities are poor, the sector is disorganized and unstructured, and the informal activities are illegal. Vanek et al. (2012) also recognized the street vendors and hawkers as informal economy. Similarly, Chen (2012) stated that formalizing the informal economy would need a comprehensive policy. Due to specific characteristics of street vendors on easiness of entry, the street vendors are always present in different cities with different level of economic development. In Bangkok, for example, the number of street vendors is significant because of similar factors with other Asian cities. Bangkok exhibited good practices in handling street vendors, for example, the presence of Chatuchak Weekend Market to reduce the number of on-street vendors at roadsides. The sellers in Chatuchak market were ex-street vendors. Other practice is the utilization of open spaces for street vendors during certain days (Suharto, 2002).

The dilemma of street vendors experienced by Jakarta Metropolitan and Bandung City. Jakarta, for example, during the period of 30 years was not able to solve the street vendor's dilemma. During that period, until the present administration of Jakarta Metropolitan under Governor Mr Joko Widodo or Jokowi, the approach to resolve the dilemma was rested on the power of enforcement, eviction and command and control. As a result, physical resistance was received by the city authority. This can be seen rather a superficial than sustainable solution.

Similarly, in Bandung City, the long traditional way of handling the street vendors has created strong resistance from street vendors who were mostly urban poor. The use of special police force in dealing with street vendors by previous city authorities was prominent but notoriously recognized by urban pressure groups as inhumane approach. As a result, the work of resolving street vendor issues in the city has never been done in a comprehensive manner until today. The command and control instrument has been prevailing for quite long time, until the new style of leaderships emerged.

\section{TWO ICONIC LEADERSHIPS}

Two emerging leaderships in Jakarta, as exhibited by past Governor of Jakarta (Joko Widodo is presently President of the Republic of Indonesia), as well as in Bandung, as demonstrated by Mayor of Bandung City, have become a new iconic political leadership in Indonesia that attracts most middle income level citizens to support them. Their fresh idea to develop the cities, courageous act to break-through the rigidity of bureaucracy, and new approach to deal with persistent problems of urban poor are among key factors that lead them to be iconic leaders.

Whilst a conventional image of a political leader in Indonesia is commonly depicted and perceived (by most people) as corrupted, building grandeur self-image with a mentality to be served not to serve, keeping distant with people except during election season, inflexibly to current regulation - regulation is regarded as the goal not the tool to achieve goal, lack of innovation, monotonous, reluctant to understand the problems from the first-hand, quantity oriented disregard the quality of accomplishment, refuse to accept criticisms particularly from opponent and whenever criticism is delivered in an improper manner, and other negative images of the Indonesian political leaders. With this longstanding perceptions of the people on political leaders, the emergence of promising leaders, as reflected in their track records, during their terms were warmly welcomed by 
middle income people. The middle income people are being the catalyst for other strata of urban community, particularly among the low income people. The middle income people are the most well informed people as they are more accessible to the information well educated. Meanwhile, the high income citizens are the minority and they are usually away from the politics.

The emerging leaderships in Jakarta and Bandung were noticeable when Joko Widodo (Jokowi) and Basuki Tjahaja Purnama (Ahok) were elected Governor and Vice Governor of Jakarta, and Ridwan Kamil (Kang Emil) was elected Mayor of Bandung City. Joko Widodo brings a new term in managing city, the "blusukan" (proactively identify the problems by visiting source of the problems). By doing the blusukan, Jokowi understands the root-cause of the problems and immediately takes actions to cope with the problems and issues. However, the actions taken by the Governor were not always smoothly implemented all the times since majority of the members of city councils were from the opposition parties. The City Council members from the opposition parties, most of the time, hampered the programs, particularly during budgeting and implementation phase. For instance, when the first time the Governor launched the KJS (Kartu Jakarta Pintar - literally means Smart Jakarta Card), a break-through of education subsidy to the citizens, a City Council member criticized the Governor for the programs as overlapping (Kompas, 21 Dec 2012), and the Medium-term Plan of Jakarta was unclear (Merdeka, 13 March 2013). The essence of these criticisms was simply criticizing regardless of accuracy and appropriateness of the substance of the issues for checks and balance function of the city councils.

The study attempts to understand the way these two iconic leaderships in Jakarta and Bandung, with all their weaknesses and constraints, cope with the dilemmatic problems of street vendors, and tries to contrast the two in terms of the impacts to the city by employing certain methodology.

\section{METHOD OF STUDY}

This study was undertaken by doing field observation, interview with actors and stakeholders, internet research, and using secondary information. The study takes Jakarta and Bandung Cities as the case, since the leaders of these two cities show outstanding leadership, those desired by most people.

The discussion is focused on two different approaches on how to manage street vendors towards better city for all. In most cases, illegal street vendors created negative urban environmental impacts that bring the city into dilapidated condition. From Surakarta and Jakarta cases (with the same leadership style because of the same person), the style to cope with street vendors was emphasized on providing incentives for the street vendors. In the case of Bandung ease, disincentive was applied to buyers or customers to discourage street vendors to operate; hence street vendors would not operate without customers.

\section{TYPICAL STYLES OF THE CITY GOVERNMENT ON STREET VENDORS HANDLING}

There are four styles of the city government in handling street vendor's issues with respect to approach i.e. incentive-disincentive of customer-street vendor. The styles are (1) incentives to street vendors (2) disincentives to customers (3) disincentives to street 
Ariva Sugandi Permana, Norsiah Abd Aziz \& Ho Chin Siong

Leadership Styles: Incentive or Disincentive Approach in Addressing Street Vendor Problems in Jakarta and

Bandung, Indonesia

vendors and (4) incentives to customers. Table 1 shows two leaderships exhibited in Jakarta Metropolitan and Bandung City in managing street vendors with minimum social problems while promoting urban environmental condition and welfare of the citizens.

Table 1 Various Approach on Street Vendors Handling in Indonesian Cities

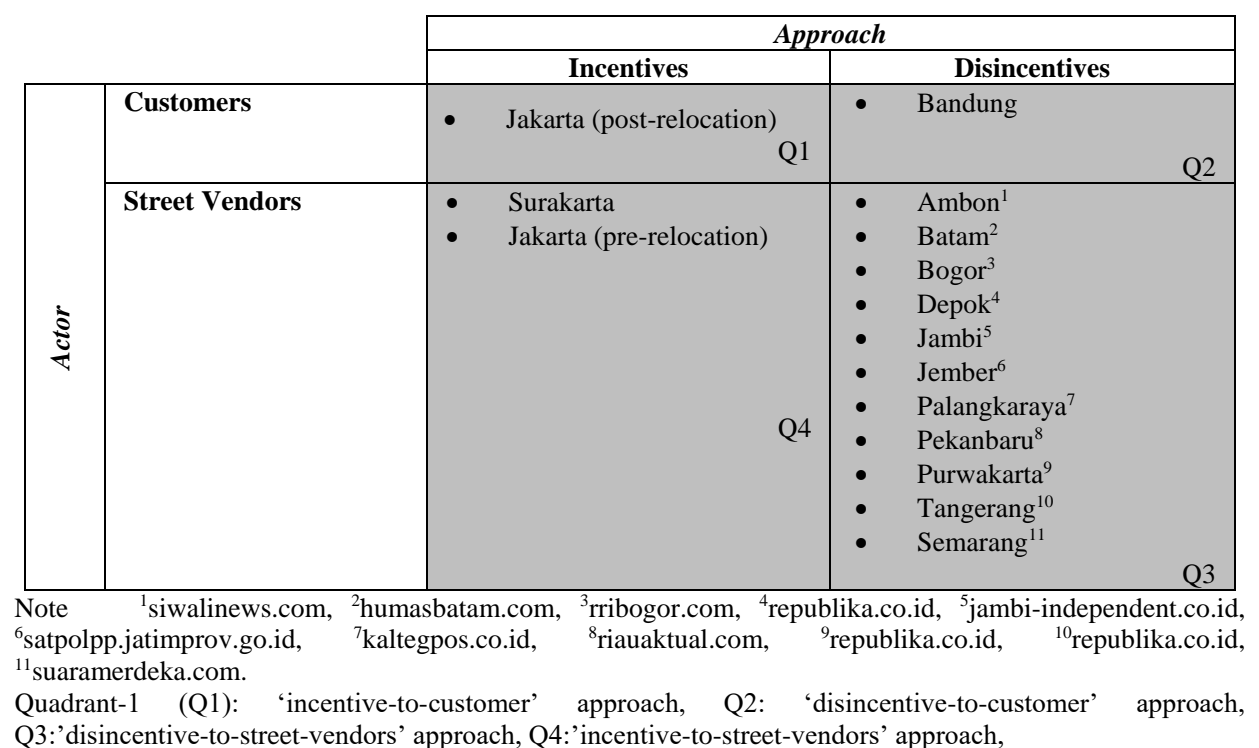

The 'incentive-to-street-vendor' style, to certain extent, is the most difficult approach in terms of patience, determination, resistance, plan and time. But this approach is the most humane and reasonable attitude towards people. Rational street vendors would prefer this approach because of various incentives they receive. Amid the incentives received by street vendors, the implementation does not necessarily smooth and immediately accepted by street vendors. For so long, the level of distrust of people to the government in Indonesia has been high. In the past and at present, most public service officers have no empathy to the problems of poor people. The mentality of 'if could be made difficult why should be made easy' of the public service officers in serving people still exists. Practically, the government needs and intensely approaches and entertains the people's needs only in 5-year interval where general election takes place. By this condition, every single government program would be received cautiously and scrutinously by people, even incentive for them would be resisted first prior to acceptance.

The 'disincentive-to-customer' approach was firstly introduced by Mr. Ridwan Kamil or Kang Emil, Mayor of Bandung. He realizes that 'disincentive to street vendors' approach, which so far been implemented in Bandung City and most cities in Indonesia, could only create strong resistance from street vendors. As an educated people who received master degree from a US University, Mayor of Bandung fully understood this situation. The pilot program was applied in some protocol road in Bandung City such as 
Jalan Merdeka, Jalan Asia-Afrika, Jalan Dalem Kaum, and Jalan Kepatihan and the program was resisted by the street vendors.

The 'disincentives-to-street-vendors' style was the most popularly known and widely applied by the city government in handling street vendors. Amid storing latent social problem, this approach is very popular among Indonesian city authorities for some reasons: (1) The easiest way for most city authorities in Indonesia, which are commandand-control-heavy (2) Instant results (3) Deliberative planning is not necessary (4) Inexpensive, and (5) needs only physical power. With the politician-type of city leaders, business-as-usual government, and lack of pressure groups, the 'disincentive-to-streetvendors' type is no wonder the most popular. This approach is hopefully gradually vanished when the elitist regime of the government gone as the country democratically matured.

The 'incentive-to-customers' is rarely implemented. Again, in the post-relocation phase of street vendors in Jakarta, this 'incentive-to-customers' is implemented by providing facilities such as free $\mathrm{Wi}-\mathrm{Fi}$, escalator, easy parking, children play port, and door prizes to encourage customers to visit and purchase.

\section{SURAKARTA'S AND JAKARTA'S CASES: INCENTIVES TO STREET VENDORS}

Present Governor of Jakarta, Joko Widodo, was formerly Mayor of Surakarta during the period of 2005-2010 and 2010-2015 (Wikipedia, 2014). Joko Widodo elected the second term of Mayor Surakarta by more than $90 \%$ votes without campaign, because of his ability to serve the citizens to cope with the root problems of health and education. Health and education are two basic needs of the citizens that were clearly understood and appropriately addressed by Joko Widodo. All citizens enjoyed this facility. This condition has made up more than $90 \%$ of citizens voted Joko Widodo for second terms of Mayor of Surakarta.

\section{Banjarsari, Surakarta Case}

Banjarsari Surakarta and Block G Pasar Tanah Abang Jakarta cases are two good examples how incentive was able to solve persistent problems with stubborn street vendors and hawkers. The growing problems of street vendors and hawkers in many cities in Indonesia, including Surakarta and Jakarta created many urban problems namely traffic jam, over-crowdedness, inviting crimes, uncleanliness and other social problems, since the street vendors and hawkers occupied urban public spaces such as walking lane, roadside, parks, and other spaces. To deal with the street vendors and hawkers' problems, most of the city governments in Indonesia generally carry out "traditional" procedures which are enforcing street vendors to vacant the occupied public land by employing special police force (Gautama, 2011). The "traditional" procedure is considered as a short-cut, inexpensive and easy way to cope with the problems, which does not need specific treatment. The procedure does not offer comprehensive resolution to the problems. It is an on-off situation and provides temporary solution. Immediately after action was taken, the street vendors cleared from the street and after sometimes they returned to the street. The act also creates strong resistance from the street vendors, generates social problem, and keeps urban poverty exists. This approach does not, therefore, solve the root-cause of the problems. 
Ariva Sugandi Permana, Norsiah Abd Aziz \& Ho Chin Siong

Leadership Styles: Incentive or Disincentive Approach in Addressing Street Vendor Problems in Jakarta and

Bandung, Indonesia

The activities of street vendors and hawkers are merely economic activities. The negative impacts of the street vendors' activities are then by-product of them. While the government is unable to create sufficient formal jobs, the street vendors and hawkers' issues exist because of urban poverty and difficulties in getting formal jobs. The city government of Surakarta under Joko Widodo's administration attempted to include this social issue in resolving the street vendors' issues. The city government realizes that the capability of the government to create formal job is limited and thus informal economic activities like street vendors is still needed. Joko Widodo also thought that street vendors should be empowered by facilitating them with appropriate place and environment (Gautama, 2011). The city government of Surakarta did different approach, which was diametrically different with what was usually done by most city governments in dealing with street vendors and hawkers.

Based on long-term observation on the street vendors activities in some big cities in Indonesia namely, Jakarta, Bandung, Semarang, Surabaya and Pontianak, the characteristics of street vendors and hawkers in these capital and secondary cities of Indonesia were normally signified by the following attributes: (1) Illegal or not recognized by laws (2) small individual financial capital with only subsistence economy characteristics (3) irregular operation hours with non-permanent business place (4) laborintensive than capital-intensive feature but with small number of workers per unit of business (5) run by unskilled people or without specific skill (6) irregular commodities according to market and skill (7) their business places are where lavish customers exist. The last feature has turned into the basis of street vendors handling in Bandung City. It is discussed later in other section.

At the initial stage of the idea to relocate street vendors in Banjarsari Surakarta was strongly opposed by the vendors. They dubbed their hesitation on whether or not the government of Surakarta City would be able to guarantee on equivalent earning income when they were in Banjarsari. They proposed to the city government not to be relocated to other places rather they preferred to be reorganized at the present place. However, the Surakarta City Government insisted on the plan for the main reasons of the environmental impacts, particularly on cleanliness of the city and traffic constraint. City government also argued that the relocation of Banjarsari's street vendors was urgent because of fast growing number of street vendors that would probably worsen the social implications when the relocation took place. Significant increase on urban environmental impacts would also take place with the increasing number of vendors, the needs of more open and urban green spaces for the city, and also pressure from community surrounding the area expressing their complaints on bad impacts of street vendors' activities on the environment and the property. The street vendor activities have impacted the price of property to be significantly collapsed.

The strong resistance, as exhibited by street vendors, did not change the standpoint of the city government, since the city government indisputably confident that the relocation was not at all the eviction. Through the relocation plan, city government ensured that illegal status of street vendors would actually be promoted to legal body by placing them in a legal venue, and empowered them to be legal partners of city government in providing informal jobs, within the overall frame of developing people's economy. This glorious plan, which would not be clearly understood by the street vendors, was translated smartly and accurately by the city government by employing 
business-like lobbies that precisely win the heart of the street vendors. For street vendors who are mostly Javanese origin, the feeling of 'diwongke' (a Javanese word that literally means: being treated humanely) is the highest hierarchy in the Javanese reverence system. The city government fully understood this Javanese culture.

To respect the feeling of diwongke of the street vendors, the Mayor of Surakarta organized business-like lobbies by inviting the street vendors for free lunch or dinner again and again without at all discussed the relocation plan. These free lunches and dinners were organized for more than 50 times. After more than fifty times heart-to-heart meetings with the street vendors, Mayor Joko Widodo told the group on the relocation plan. The discussion on the relocation plan was then carried out in relax manner and heartto-heart exchange views. The discussion led to a reasonable proposals and conditions from them. Three major conditions for the relocation were proposed to the Mayor. The major points of the proposals were: (1) they wanted to have appropriate building and location of the new place (2) they needed assurance of from the Mayor that old customers visited the new place (3) they needed the Mayor to ensure that their income is not affected. Mayor Joko Widodo responded that all three points of the proposal were accepted with some notes. He could not give a warranty that their income would be maintained rather, he would make the best efforts to support the increase of income for the good of street vendors.

To implement the commitments of the Mayor, in parallel with the lobbies, the Pasar Klithikan Notoharjo, was refurbished and restored to appropriately receive the relocated street vendors of Banjarsari. The street vendors were also brought to see the new location. Along with this, City Government had also re-routed some of the city public transport routes to pass the new location to encourage citizens to visit and shop at the new location. Continuous commercials in local media (TV, radio and local newspapers) to promote the new location of ex-Banjarsari's street vendors were organized. Thus, the relocation of street vendors of Banjarsari was successful under Mayor Joko Widodo without creating social problems. This effort did not succeed under two formers Mayor of Surakarta, the predecessors of Mayor Joko Widodo.

The keyword of this success story is 'relocation' not 'eviction'. 'Relocation' contains the spirit of 'diwongke' of the street vendors. The socio-economic rights of the street vendors, as citizens, are respected. Meanwhile, 'eviction' ignores these rights and focused only on the goal of authority i.e. pseudo-quality of the city. This is the significant different between the traditional approach of 'eviction', which is normally employed by most Mayors or city authorities in Indonesia, and new approach of 'diwongke' as introduced and successfully exhibited by Mayor Joko Widodo. During the preparation of this article, Joko Widodo or Jokowi is the Governor of Jakarta, and perhaps when this article is published he has already been elected the- $7^{\text {th }}$ President of the Republic of Indonesia. Joko Widodo has certainly brought a new paradigm in the public services positions from 'to be served' and 'elitist' style by keeping his image high 'to serve' and 'people-oriented' style of governing. The elitist style of governing has been exhibited by, for example, ex-New Order regime leader Soeharto, and perhaps being maintained by current style of the presidency, which is widely known by people as SBY-style. This style is not preferred by most of people as most survey placed Joko Widodo as the preferred style of the leadership of future Indonesia. 
Ariva Sugandi Permana, Norsiah Abd Aziz \& Ho Chin Siong

Leadership Styles: Incentive or Disincentive Approach in Addressing Street Vendor Problems in Jakarta and Bandung, Indonesia

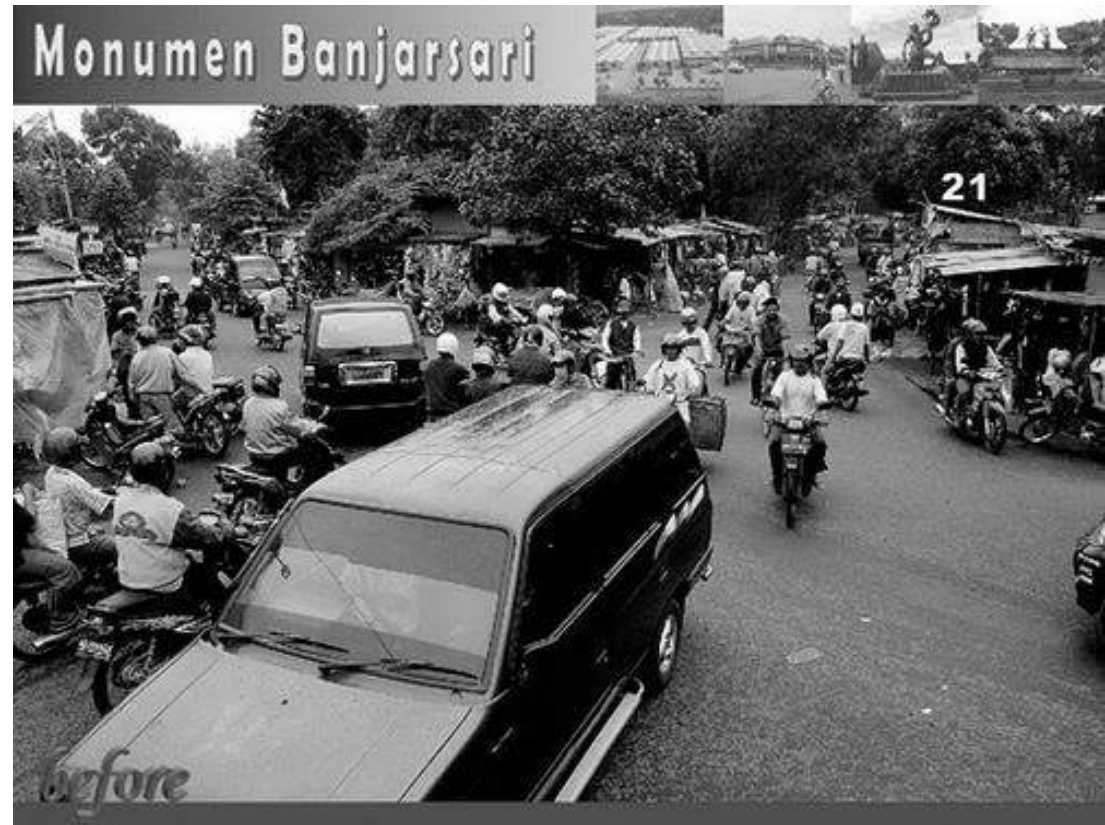

Figure 1: Street Vendors at Banjarsari before relocation Source: aerbeaerbe.wordpress.com

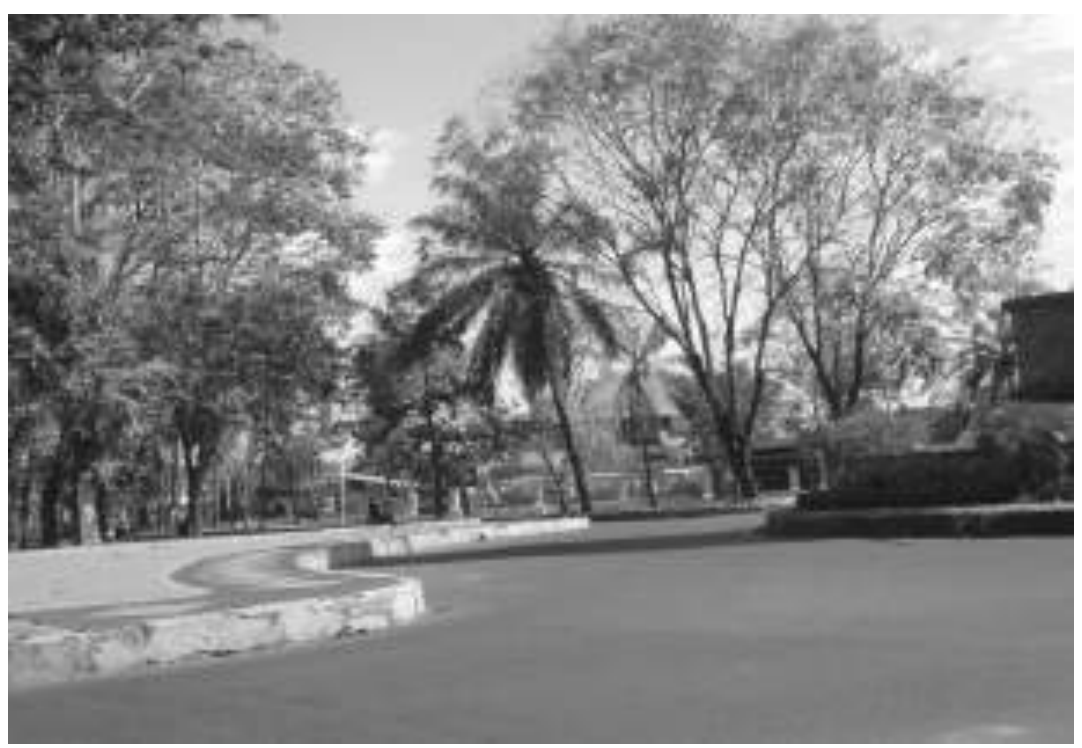

Figure 2: Banjarsari After Street Vendors were relocated Source: azisturindra.wordpress.com 


\section{Block G Tanah Abang, Jakarta Case}

Joko Widodo, the former Mayor of Surakarta, who was able to elevate Surakarta as the center of Javanese Culture and Tradition has been declared by the City Mayor Foundation Organization (www.worldmayor.com) as one of the best 10 mayors in the world. His clean and excellent track record, Joko Widodo has been elected Governor of Jakarta; the Capital City of Indonesia with 12 million populations defeated the incumbent governor Fauzi Bowo. The past governors have bequeathed numerous problems of urban flooding, traffic congestions, public transport system, slums, illegal squatters, horizontal conflicts, street vendors and other problems.

Street vendors' problems in Jakarta are more complex than Banjarsari's street vendor case. Jakarta is the showcase of racial diversity of Indonesia. Various races with different culture and attitude with low education level mixed together add the problematic situation of street vendors in Jakarta. The street vendors in Tanah Abang could also generate 'easy-amid-black money' stems from the illegal charge of 'uang jago' (security fee) that ranges from equivalent to USD 5 to 15 per day per vendor depending on the scale of the street business. The security fee was also illegally applied to parking fee. Since the parking space in Tanah Abang was not properly and adequately provided by the government, the manual arrangement of parking lots and fees were adopted. Every visitor was free to park their cars or motorcycles wherever they found enough space to park and pay unofficial parking charge to illegal field officer. As a result, various and complex situation such as traffic jam, crimes, circulation of illegal money took place. The illegal security fees charged from street vendors and illegal parking could reach tantamount to USD 50,000 per day (personal communication with some field sources). This problem could not be solved by four previous governor of Jakarta, since their approach was traditional 'eviction-way' business as usual. None of them innovatively introduced new approach to solve the problem with minimum social consequences.

The street vendors in Jakarta as well as other cities in Indonesia were typical with respect to causes and actors. The causes of flourishing street vendors in Jakarta were slightly unique and different with other cities. The push and pull factors were economic motives given limited skill of people, easy money, which make easier to earn money in Jakarta for the same level of education and skill compared to other cities. Other factors were sixty percent of the monetary circulation takes place in Jakarta, the presence of potential buyers of low income citizens, and easy to start business. The actors are certainly rural migrants with low level of education and skill.

With the complexity of the street vendors' problems in Jakarta, and Tanah Abang's street vendors, the solution offered by the new governor of 'New Jakarta' was a critical test-case by the Governor. It is critical because of the success or the failures will determine his future political career path towards highest political position, the Presidency. During the gubernatorial campaign, Joko Widodo emphasized his program into six: (1) Education subsidy through 'Kartu Jakarta Pintar, KJP' (Smart Jakarta Card), (2) Citizens Healthcare by introducing 'Kartu Jakarta Sehat, KJS' (Healthy Jakarta Card) and (3) Gradually minimizing flooding problems (4) Promoting excellent public transportation system by strengthening Busway system, developing monorail system and Jakarta Mass Rapid Transit System, (5) Bureaucracy reform by improving services to the Citizens (6) Slums upgrading and street vendors management. 
Ariva Sugandi Permana, Norsiah Abd Aziz \& Ho Chin Siong

Leadership Styles: Incentive or Disincentive Approach in Addressing Street Vendor Problems in Jakarta and Bandung, Indonesia

The problem of street vendors in Tanah Abang area was very desperate. At least four predecessors of Governor Joko Widodo were unable to solve it properly because of complicated issue that rooted from intensive rural-urban migration, dire urban poverty, lack of urban jobs, involvement of gangsters and criminals, the involvement of black politicians, and potential earning source. The approach of four previous governors was merely on short-term solution by evicting street vendors without, at all, looking at the root-cause of the problem. As a result, the problem persists.

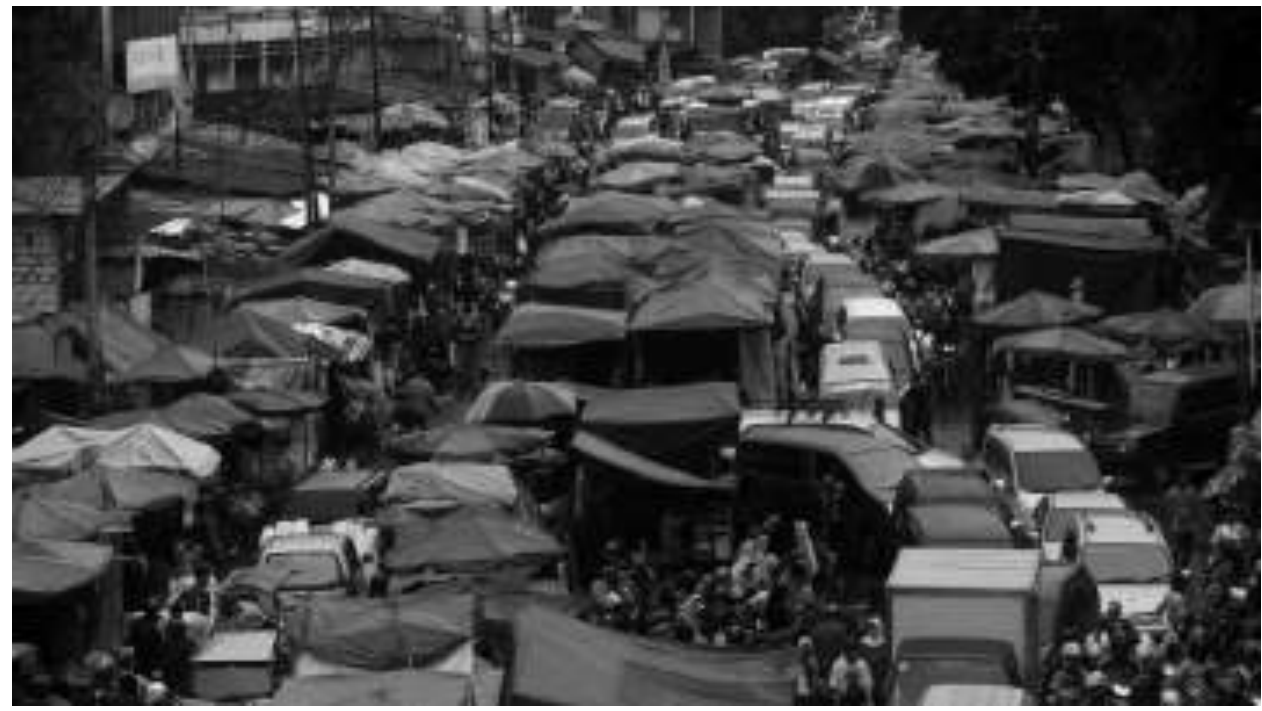

Figure 3: Street Vendors at Tanah Abang: Main Users are neglected

Source: kompas.com

The severity of the problem of street vendor in Tanah Abang, prior to the relocation to Block $G$, is shown in Figure 3. The most obvious situation as exhibited in Figure 3 is that the main function of road to accommodate traffic was only about $15 \%$ and the remaining $85 \%$ was occupied by street vendors. This situation constrained traffic and distracted people to visit Tanah Abang, the largest traditional market in Asia. Even the locals with high income reluctantly visited Tanah Abang unless a very important business in Tanah Abang was necessary. The severity of the problem is self-explained by the fact that four governors (three ex-generals of the army and one civilian) were unable to comprehensively solve the problem.

With sufficient experience in relocating street vendors in Banjarsari Surakarta, the present Governor of Jakarta employed the same approach i.e. 'incentive-to-streetvendors' at pre-relocation phase and then followed 'incentive-to-customers' at the postrelocation phase. The progress surprisingly took less than 2 months in comparison to 1year relocation process of the street vendors of Banjarsari Surakarta. This is perhaps because of some reasons: (1) Joko Widodo, the present Governor of Jakarta, has ample of experience in dealing with social-engineering process in the relocation of street vendors (2) Tanah Abang's street vendors are most probably more open and straight 
forward, as long as they can earn money legally with government recognition amid difficulty in getting formal jobs in Jakarta, the relocation would be acceptable (3) the street vendors realized that being a legal entrepreneur in Jakarta was difficult.

Joko Widodo commenced the relocation plan by visiting street vendors and targeted relocation place at Block $G$ Tanah Abang several times. Block $G$ is located at the same premise of Tanah Abang. The new location at Block $G$ was refurbished days and nights. The Governor even checked and controlled the refurbishment activities in the midnight (Tribun News, 15 August 2013) to accelerate the completion of the place. Thus the relocation plan could be carried out on time. The refurbishment also provided facilities such as escalator and overpass to ease visitors to Block $G$.

Upon 95\% completion of the refurbished location for street vendors' relocation at Block $\mathrm{G}$, the street vendors were invited to observe the new location. The total capacity of Block $G$ was 968 units, while number of street vendors relocated was 941 vendors (Antara News, 12 August 2013). Thus all vendors were secured to get the unit. Other incentives for post-relocation were also provided. These incentives included 3-month free rental fee including water and electrical bills for the registered vendors who were willing to relocate. With this offer, all the street vendors were willing to relocate to a new place at Block $G$. In the meantime, Government of Jakarta is continuously improving the Block $G$ to attract more visitors to shop and would then keep the street vendors off the street. The impact of relocation in reduction of traffic jam and beautification of the city is shown in Figure 4. The figure exhibits two contrasting situation after the relocation took place (left) and before the relocation (right). Many citizens commended the efforts of Governor Joko Widodo as successful without significant social issues.

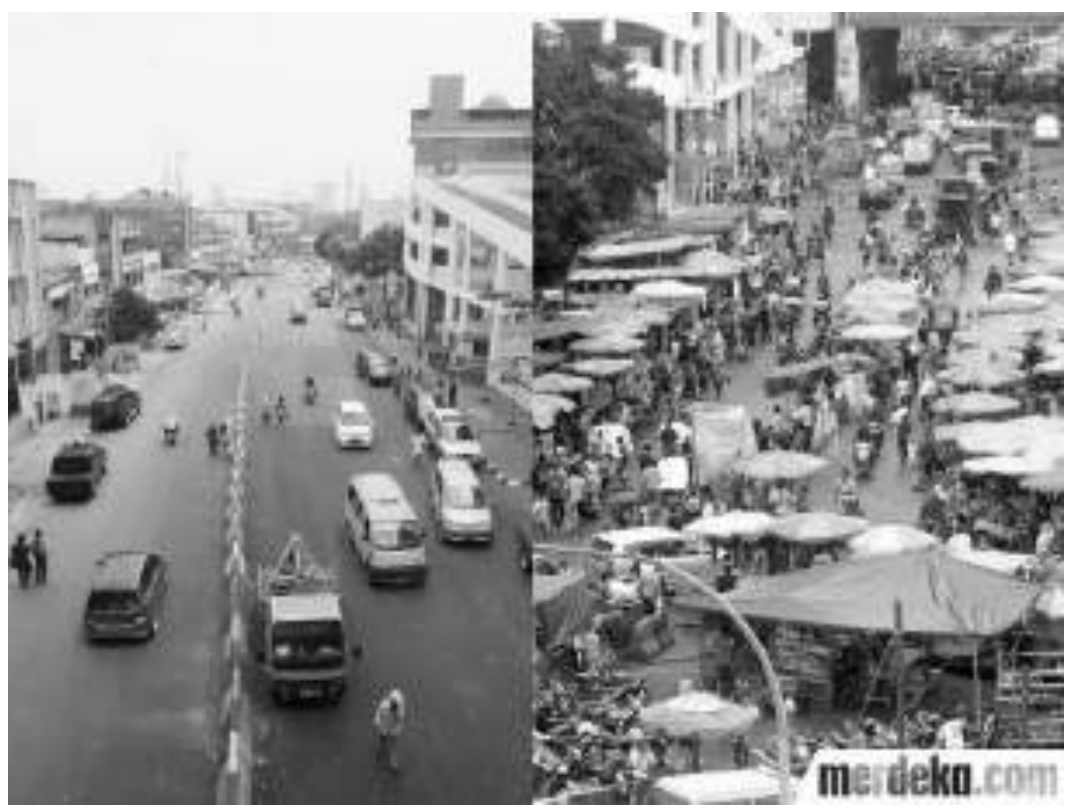

Figure 4: Post-relocation (left) and Pre-relocation (right) of street vendors of Tanah Abang

Source: merdeka.com 
Ariva Sugandi Permana, Norsiah Abd Aziz \& Ho Chin Siong

Leadership Styles: Incentive or Disincentive Approach in Addressing Street Vendor Problems in Jakarta and

Bandung, Indonesia

From the two plans implemented by Joko Widodo in dealing with street vendors, one crucial point can be drawn. The crucial point is an incentive to actors, street vendors and customers are more successful than disincentive one with respect to minimizing the social cost of street vendors. Survey on 112 randomly selected costumers those directly or indirectly involved in street vendors activities such as customers, visitors, and sellers shows that $98(87.5 \%)$ respondents perceived their agreement and satisfaction with the policy, $5(4.5 \%)$ respondents were neutral, and $9(8.0 \%)$ respondents perceived their disagreement and dissatisfaction of the policy. The main reason of dissatisfaction of the respondents is their concern if the relocation would reduce their income.

In contrast, disincentive-to-street-vendors approach is totally failed, as social costs and losses are high. Disincentive-to-customers approach, on the other hand, is yet to prove as successful or failure, until Mayor of Bandung City attempted to implement this policy to cope with street vendors problems.

\section{BANDUNG'S CASE: DISINCENTIVES TO CUSTOMERS}

Amid most of city government implementing Q3 approach (disincentive-to-streetvendors), Bandung City Government applies 'disincentive-to-customers' approach (Q2) as illustrated in Table 1. This approach was based on 'no demand leads to no supply'. If no customers (demand) presence, street vendors (supply) will diminish. There are several 'whys' following the selection of this cure. Why Bandung City government did not apply disincentive-to-street-vendor approach? Or why Bandung City Government did not apply incentive-to-street-vendor approach? Or why Bandung City Government did not apply incentive-to-customers approach? Mayor of Bandung has considered various options. The notorious approach of 'disincentive-to-street-vendors' would be rejected by the Mayor outright since this approach would not work well. The incentive approach, as implemented in Surakarta and Jakarta, certainly would not be the first choice since the annual budget of Bandung City would not be able to support the implementation of this approach. This is reasonable if it is to be compared with Jakarta, because Jakarta has practically no financial problem. However, this option would become irrational compared to Surakarta. Surakarta is smaller than Bandung in terms of population, administrative area, and annual budget. With these two opposite situations, the reason behind the application of disincentive-to-customers approach was most probably because of halfhearted innovative idea of being 'just different'.

The approach of disincentive-to-customers was also based on the fact that customers of street vendors were financially sound than the street vendors. Thus an option to impose the 'disincentive-to-customers' approach is rationalized. The Mayor is also uncertain of the effectiveness of this policy, since the approach was applied only at certain area (zone) of primary roads (protocol roads) at central business district and other prime areas, which is currently on trial period. During this trial phase, many street vendors protested the city government (Detiknews, 17 February 2014). Street vendors were also playing hide-and-seek with the authority to safeguard their business while operating illegally at designated areas.

Bandung city government has actually provided a relocation place in Pasar Gedebage (Gedebage Market) for most of the street vendors. However, unlike the success story of Surakarta and Jakarta, the new location has insufficient facilities and no 
guarantee of visitors. The new location is presently a traditional market, and abandoned industrial estate of Bandung City, and it is too far from the city center with poor accessibility to the city center amid close to a main arterial road of Bandung City. In short, the new location is not ready for the relocation and hence most of street vendors rejected the program.

The results of this program are unknown since the policy is just commenced for implementation by present Mayor of Bandung City. The policy was actually promulgated in 2011 through the formulation of City Regulation No. 4 Year 2011 on the Management of Street Vendors in Bandung City, particularly on Chapter 24 Clauses 1 and 2. The former Mayor of Bandung City was not confident to implement the regulation since he was aware on the social impacts caused. Therefore he opted to implement traditional way in dealing with the street vendors, which is forced eviction.

Perceptions of relevant stakeholders on the program were investigated. Seventy respondents i.e. visitors of the area (20), customers-to-be (15), street vendors (10) and shop owners (25) perceived different feelings about the implementation of this policy. Fifteen out of 20 the customer-to-be respondents agreed with the policies, 3 respondents disagreed, and the remaining 2 were neutral. Ten out of 10 street vendors show their disagreement by noting that earning money is the basic rights of the citizens. They would keep selling although they might play hide-and-seek with the law enforcement officers. A street vendor noted that she would obey the authority if the authority would relocate them to an appropriate place with sufficient facilities as it has done by Government of Jakarta City. It is not surprising that all of 25 shop owners were totally agree with the policy, because they were badly impacted with the presence of street vendors in front of their shops. Two customers who were fined USD 25 (the maximum fine is USD 80) showed their disagreement with the policy as they did not aware about the policy. They suggested Bandung City Government must replicate the policy of Jakarta in dealing with street vendors.

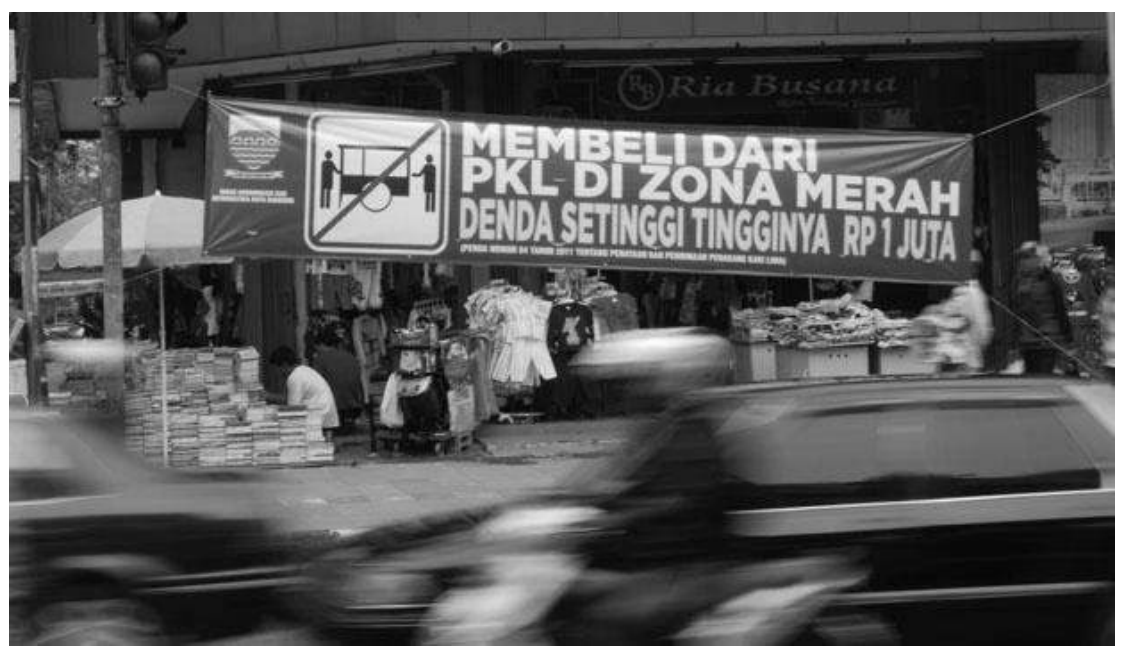

Figure 5: Designated Free-Street Vendors Zone. The Banner reads: Shopping at Street Vendors at Red Zone will be fined by maximum IDR 1 million (USD 80) Source: Tempo.co 
Ariva Sugandi Permana, Norsiah Abd Aziz \& Ho Chin Siong

Leadership Styles: Incentive or Disincentive Approach in Addressing Street Vendor Problems in Jakarta and

Bandung, Indonesia

The mixed feeling of the respondents shows that the policy is not perfectly match with the present conditions. Unlike Jakarta, Bandung City's disincentive-to-customers policy is not equipped with comprehensive facilities plus incentive to street vendors. The street vendors are, by design, being neglected to gradually disappear because of zero demand. The zero demand leads to zero supply. Without sufficient incentive to the street vendors, this approach would only become a two-side-of-the-same-coin with disincentives to street vendors which commonly carried out by many city authorities in Indonesia.

\section{CONCLUSIONS}

Among four possible options to deal with persistent and exacerbating problems of street vendors, the disincentives-to-street-vendors is the most widely employed option for a number of reasons (1) the option is the easiest one to implement since the only requirements to implement the option are physical power and authority. Physical power is definitely abundant at the city government. So far, all city governments in Indonesia utilized a special police force under city government called Satuan Polisi Pamong Praja (Satpol PP), (2) The authority of the city government to exercise their power in dealing with street vendors, which is assigned by city regulation, is already in place. (3) Lack of innovative idea of the city government to exercise their power.

Learning from two different approaches, as exhibited by Jakarta's and Bandung's cases, incentive to both street vendors and customers is seemingly still the best option leading to permanent solution of the street vendors' issue. Disincentives would not work because of socio-economic conditions of the actors. Most actors, of both street vendors and customers, are socially disadvantage and economically underprivileged people. They are just implementing their constitutional rights to earn money, although at the wrong place. In the meantime, Government could not provide appropriate place for them to do business or provide sufficient formal jobs. This dilemma should actually be recognized by the city government to implement their policy on street vendors. Joko Widodo, the former Governor of Jakarta and Mayor of Surakarta acknowledged the situation and successfully managed the issues of street vendors in Surakarta and Jakarta. Although this model has not yet fully resolved the overall issues of the street vendors the present approach and ongoing process gives a better results towards comprehensive solution on the persistent problem of street vendors in most cities in Indonesia.

\section{REFERENCES}

Carr, M., MA Chen and J. Tate (2000). Globalization and Home-based Workers. Feminist Economics. 6(3):123-142.

Charmes, J (1998). Informal Sector, Poverty and Gender: A review of empirical evidence. Background paper for World Bank. World Bank Development Report 2000 Washington DC.

Chen, MA (2001). Women in the informal sector: A Global picture, the global movement. SAIS Review, 21(1):71-82. 
Chen, MA (2012). The Informal Economy: Definitions, Theories and Policies. WIEGO Working Paper No 1. Women in Informal Employment: Globalizing and Organizing (WIEGO).

Chirisa, I (2009a). Prospect for the asset based community development approach in Epworth and Ruwa, Zimbabwe: A housing and environmental perspective. African Journal of Housing and Culture, 1(2):28-35

Chirisa, I (2009b). The geography of informal sector operation: a perspective of urban Zimbabwe. Journal of Geography and Regional Planning, 2(4):66-79.

Garoma, BF. (2012). Determinants of microenterprise success in the urban informal sector of Addis Ababa: A multidimensional analysis. Unpublished PhD Thesis, Institute of Social Studies, Rotterdam, The Netherlands.

Gautama, A. (2011). Communication Strategy of Surakarta City Government in Relocating Street Vendors. Unpublished MSc Thesis, Diponegoro University, Indonesia.

ILO (2000). Employment and social protection in the informal sector. Committee on Employment and Social Policy, International Labor Office, Governing Body. Geneva, Switzerland.

Suharto, E. (2002). Human development and the urban informal sector in Bandung, Indonesia: The poverty issue. New Zealand Journal of Asian Studies 4(2):115-133.

Timalsina, KP. (2011). An urban informal economy: livelihood opportunity to poor or challenges for urban governance, study of street vending activities of Kathmandu Metropolitan City. International Journal of Politics and Good Governance 2(2).

UN (2000). The world's women 2000: trends and statistics. New York: UN Statistical Division.

Vanek, J., M. Chen, R. Hussmanns, J. Heintz, and F. Carre. (2012). Women and Men in the Informal Economy: A Statistical Picture. Geneva: ILO and WIEGO.

\section{INTERNET SOURCES:}

Antara News Online Newspaper, 12 August 2013. Available online at:http://www.antaranews.com/berita/390190/hari-ini-pkl-tanah-abang-mulaitempati-blok-g Retrieved on 19 March 2014.

Detiknews Online Newspaper, 17 February 2014. Available online at: http://news.detik.com/bandung/read/2014/02/17/144836/2499673/486/dinilaitak-pro-pedagang-ridwan-kamil-didemo-ratusan-pkl Retrieved on 20 March 2014.

Jakarta Okezone Online Newspaper, 5 December 2013. Available online at: http://jakarta.okezone.com/read/2013/12/05/500/907444/para-istri-pejabat-pasarikut-belanja-di-blok-g-tanah-abang/large Picture of Blok G Retrieved on 19 March 2014.

Jambi Independent Online Newspaper, 28 January 2014. Available online at: http://www.jambi-independent.co.id/jinn/index.php/seputar-jambi/metrojambi/item/599-penertiban-pkl-depan-kuburan-cina Retrieved on 18 March 2014.

Kalimantan Tengah Pos Online Newspaper, 18 March 2014. Available online at: http://kaltengpos.web.id/berita/detail/4866/penertiban-pkl-berlangsungricuh.html Retrieved on 18 March 2014 
Ariva Sugandi Permana, Norsiah Abd Aziz \& Ho Chin Siong

Leadership Styles: Incentive or Disincentive Approach in Addressing Street Vendor Problems in Jakarta and

Bandung, Indonesia

Kompas Online Newspaper, 21 December 2012. Available online at: http://lipsus.kompas.com/gebrakan-jokowi-

basuki/read/xml/2012/12/21/16584287/Demokrat.Kritik.Program.Kerja.Jokowi. Retrieved on 03 March 2014

Merdeka Online Newspaper, 13 March 2013. Available online at: http://www.merdeka.com/jakarta/jokowi-jawab-kritikan-program-kerjanya-didepan-anggota-dprd.html. Retrieved on 03 March 2014

Public Relation of Batam City, 28 January 2014. Available online at: http://www.humasbatam.com/2012/09/11/wawako-tinjau-lokasi-penertiban-pkl/ Batam Retrieved on 18 March 2014

Radio Republik Indonesia Bogor (Radio of Indonesia).Available online at: http://rribogor.co/component/k2/item/590-penertiban-pkl-di-cibinong-bogorrusuh Retrieved 18 March 2014. Retrieved on 18 March 2014.

Republika Online Newspaper, 14 March 2014. Available online at: http://www.republika.co.id/berita/nasional/jabodetabeknasional/14/01/04/myuz04-satpol-pp-akan-tertibkan-seluruh-pkl-di-tangerang Retrieved on 18 March 2014

Republika Online Newspaper, 16 March 2014. Available online at: http://www.republika.co.id/indeks/hot_topic/penertiban\%20pkl Retrieved on 18 March 2014

Republika Online Newspaper, 29 May 2013. Available online at: http://www.republika.co.id/berita/nasional/jabodetabek-

nasional/13/05/29/mnkff9-stasiun-ui-ditertibkan-puluhan-kios-dibongkar Retrieved on 18 March 2014

Riau Aktual Online Newspaper, 15 November 2013. Available online at: http://riauaktual.com/berita/detail/5353/2013/11/15/dewan-dukung-penertibanpkl-taman-labuay\#.Uyfsw6Kha2o Retrieved on 18 March 2014

Siwalima Ambon Online Newspaper, 12 February 2011. Available Online at: http://www.siwalimanews.com/show.php?mode=artikel-

visi\&id=8450\&path=list-visi.html Retrieved on 18 March 2014.

Suara Merdeka Online Newspaper, 14 March 2014. Available online at: http://m.suaramerdeka.com/index.php/read/cetak/2014/03/14/255570 Retrieved on 18 March 2014

Tribun News Online Newspaper, 15 August 2013. Available online at: http://www.tribunnews.com/metropolitan/2013/08/15/pantau-pasar-blok-gjokowi-blusukan-tengah-malam Retrieved on 19 March 2014.

Website of the Provincial Government of East Java, undated. Available online at: http://satpolpp.jatimprov.go.id/site/index.php?option=com_content\&view=articl e\&id=66:operasi-penertiban-pedagang-kaki-lima-di-kecamatan-sumbersarijember\&catid=2:pemerintahan Retrieved on 18 March 2014.

Wikipedia, 2014. Available online at: http://id.wikipedia.org/wiki/Joko_Widodo. Retrieved on 09 March 2014. 